\title{
Oxygen production and consumption associated with the major autotrophic components in two temperate seagrass communities*
}

\author{
Laura Murray** \& Richard L. Wetzel \\ College of William and Mary, School of Marine Science and Virginia Institute of Marine Science, \\ Gloucester Point, Virginia 23062, USA
}

\begin{abstract}
Oxygen production and comsumption rates were determined for the various communities (plankton, sediment, and seagrass-plus-epiphytes) associated with 2 adjacent seagrass communities. one dominated by Zostera marina and the other by Ruppia maritima. Annual estimates of gross production summed for all communities were high compared to other reports (ca $1600 \mathrm{gC} \mathrm{m}^{-2}$ and 1100 $\mathrm{gC} \mathrm{m}^{-2}$ in the $Z$. marina and the $R$. maritima dominated communities, respectively). Plankton and sediment communities accounted for ca 45 and $36 \%$ in the 2 areas, respectively. Seasonal patterns of production for the 2 areas differed. In the $Z$. marina area, plankton and sediment production dominated during summer, whereas in the $R$. maritima area production of seagrass (plus epiphytes) dominated throughout the study. Temporal trends for oxygen production and consumption of the plankton and sediment components corresponded closely and suggested direct in situ utilization. However, a lag observed between production and consumption in the seagrass-plus-epiphyte component indicated indirect utilization mediated by microbially dominated decomposition and remineralization processes. The ratio of annual gross production to dark respiration $(P: R)$ exceeded 1.0 in both seagrass communities and for all components, suggesting net export and/or burial of carbon in these systems.
\end{abstract}

\section{INTRODUCTION}

Seagrass communities are characterized by diverse autotrophic and heterotrophic populations including many commercially important macrofaunal species. In addition to the vascular plants, several other components contribute to community production, including benthic microflora. This diversity in primary producers theoretically provides numerous pathways for the secondary utilization of organic matter (Thayer et al. 1975) and contributes to a greater abundance and diversity of heterotrophic organisms in seagrass beds relative to unvegetated sediment habitats (Orth 1973, Stoner 1980). Whereas direct grazing on living seagrasses tends to be limited (Thayer et al. 1975), microalgal populations (planktonic, sediment and epiphytic) provide a direct energy/organic matter source for higher

\footnotetext{
- Contribution No. 1364 from the College of William and Mary, School of Marine Science and the Virginia Institute of Marine Science

- Present address: Biology Department, Salisbury State College, Salisbury, Maryland 21801, USA
}

trophic level consumers that may equal or even exceed the trophic importance of the vascular plant (Zimmerman et al. 1979, Morgan 1980). Seagrass systems are utilized heterotrophically by a large number of epifaunal, infaunal, benthic, and pelagic macrofauna, including many commercially important species such as the blue crab (Heck \& Orth 1980). Microbial processes account for vascular plant decomposition, which provides food for yet another group of heterotrophic species.

Most previous studies on primary production in seagrass communities either have focused on the dominant vascular plant species (McRoy 1974, Zieman \& Wetzel 1980) or report estimates of total production for the entire community (Nixon \& Oviatt 1972, Neinhuis 1980, Lindeboom \& deBree 1982, Wetzel 1983). The ecological significance of the various microalgal components has received limited attention and remains poorly documented. Considerable research in freshwater (Wetzel 1964, Sondergaard \& Sand-Jensen 1978, Cattaneo \& Kalff 1980) and a few studies in marine environments (Marshall et al. 1971, Thayer et al. 1975) 


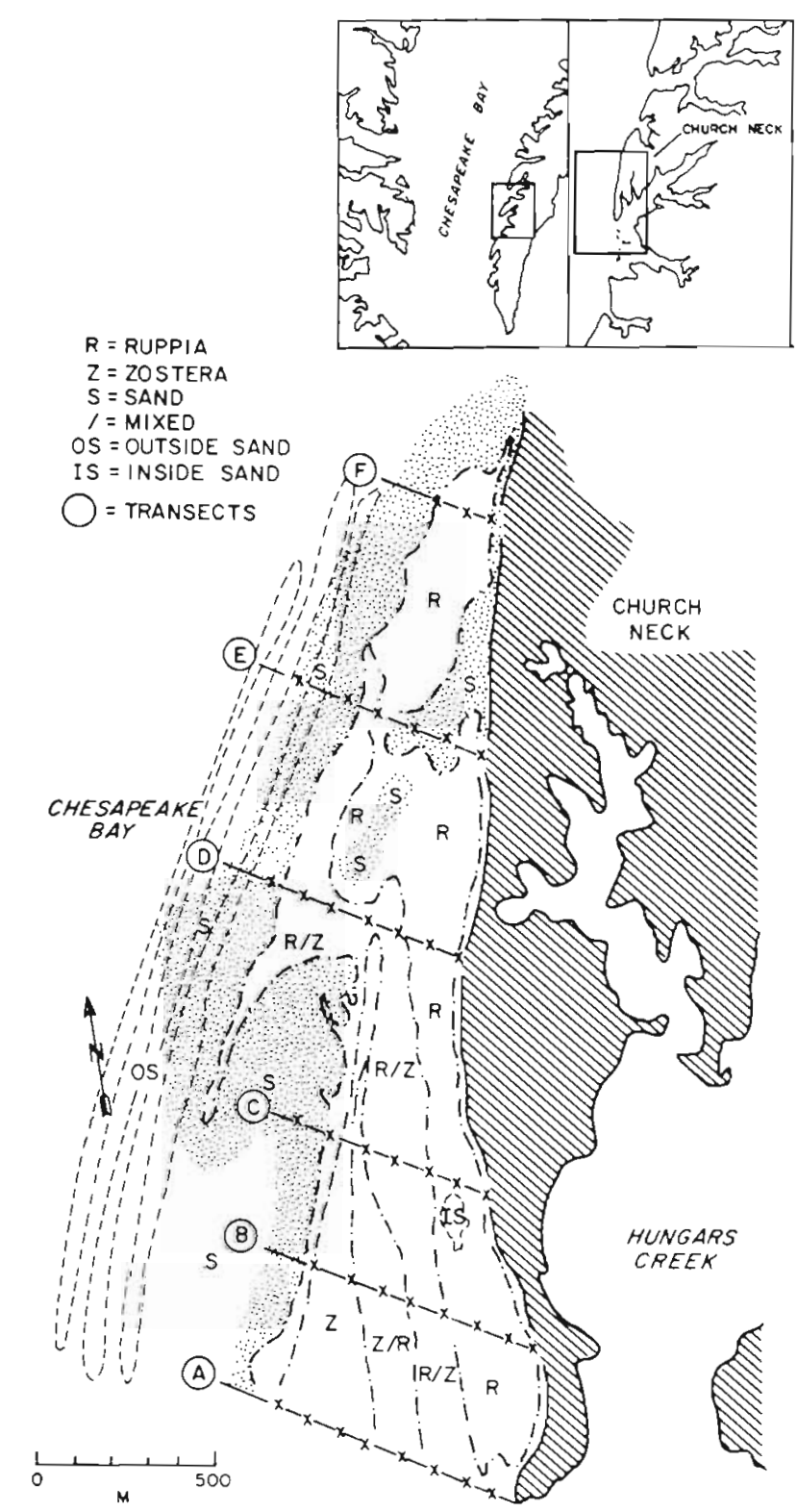

Fig. 1. Location of study site and plant community distribution at Vaucluse Shores, Chesapeake Bay, Virginia, USA

have shown that the contribution of microalgal can account for 30 to $60 \%$ of total annual community production. At certain times production by epiphytic microalgae can equal that of host seagrasses (Penhale 1977. Borum \& Wium-Andersen 1980, Morgan \& Kitting 1984).

Although several studies have examined primary production of epiphytic and planktonic algae in seagrass communities, few have coupled these with rates of consumption (Morgan \& Kitting 1984). Hargrave (1969) reported a higher benthic carbon consumption rate than could be supported by vascular plant production alone in a freshwater lake. Lindeboom \& deBree
(1982) found that both production and consumption were significantly greater in Zostera marina L. beds than in nearby unvegetated areas, indicating higher, heterotrophic metabolic activity within the grass beds. However, specific rates of production and respiration for macrophytes, epiphytes, plankton and sediment have not been quantified previously for a seagrass community.

The purpose of this study was to compare the relative contributions of several operationally defined autotrophic groups to community production in 2 adjacent seagrass communities, the principal components being seagrass-plus-epiphyte, sediment, and plankton. For this study the vascular plant and epiphyte components are combined due to the low abundance of epiphytes (Murray 1983). Concurrently, we examined oxygen respiration for the biota associated with each of these groups. Previous studies had demonstrated that seasonal patterns of vascular plant abundance were distinctly different for the 2 communities investigated, one dominated by Zostera marine $\mathrm{L}$. and the other by Ruppia maritima L. (Wetzel \& Penhale 1983). We hypothesized that seagrass systems with distinctly different patterns of abundance would also have varying patterns of microalgal production, with rates increasing during periods of declining macrophyte production. Patterns of organic matter utilization within the system (as reflected by oxygen consumption rates) would be expected to closely follow production where direct utilization was the dominant heterotrophic mode, while production and consumption for detritalbased or indirect pathways would be out of phase.

\section{MATERIALS AND METHODS}

Study site. The investigations reported here were conducted in a seagrass meadow approximately 140 ha in size located on the southeastern shore of Chesapeake Bay, Virginia, USA ( $\left.37^{\circ} 25^{\prime} \mathrm{N}, 75^{\circ} 59^{\prime} \mathrm{W}\right)$, in an area known locally as Vaucluse Shores (Fig. 1). Nearshore areas were dominated by Ruppia maritima, while Zostera marina was the dominant vascular plant occupying the deeper areas. An intermediate area was comprised of mixed stands of the 2 species. The area is partially protected from heavy wave action by an offshore sand-bar. Mean water depths in the Z. marina and $R$. maritima communities were approximately 1.0 and $0.5 \mathrm{~m}$, respectively (tidal range of $0.5 \mathrm{~m}$ ). Sediments in the study area were generally sandy and relatively low in organic content (Wetzel 1983). Ranges in salinity and temperatures were 17 to $25 \%$ and 0 to $30^{\circ} \mathrm{C}$ for both sites during this study. A more detailed description of the area has been given by Wetzel \& Penhale (1983). 
Oxygen production and consumption: general procedures. Oxygen production and consumption associated with the operationally defined autotrophic groups in the 2 seagrass communities were estimated from the rate of change in dissolved oxygen concentration during incubations using various enclosure designs described below. Dissolved oxygen concentrations were measured using a multichannel system of Clarktype polargraphic electrodes with built-in stirrers (Orbisphere Model \#2604), calibrated against watersaturated air for each experiment. Light as photosynthetically active radiation (PAR: 400 to $700 \mathrm{~nm}$ ) was monitored continuously using surface and submarine cosine-corrected quantum sensors (LiCor Model 185A) placed $20 \mathrm{~cm}$ above the sediment surface within the seagrass canopy. Temperature was recorded continuously during each incubation from sensors contained in the $\mathrm{O}_{2}$ electrodes. All experiments were conducted during mid-day hours (1000 to $1400 \mathrm{~h}$ ). Daily $\mathrm{O}_{2}$ production and consumption (e.g. dark respiration) rates were calculated assuming the mean rates over the incubation interval to be representative of the entire photoperiod (defined as $80 \%$ of daylight hours; Wetzel 1983). Estimates of seasonal $\mathrm{O}_{2}$ production and consumption were derived by defining seasons according to ambient water temperature. For the Zostera marina community seasons were defined as: winter, $<10^{\circ} \mathrm{C}$; spring and fall, 10 to $20^{\circ} \mathrm{C}$; summer, $>20^{\circ} \mathrm{C}$. For the Ruppia maritima community spring and fall were defined by water temperatures between 10 and $25^{\circ} \mathrm{C}$, while summer was defined as temperatures $>25^{\circ} \mathrm{C}$. Linear interpolations were used between consecutive monthly measurements and integrated over the year to estimate annual rates. Wetzel \& Penhale (1983) provide a detailed explanation for these seasonal definitions in relation to temperature. Because all experiments were purposefully conducted at or near optimum in situ light conditions, the extrapolated seasonal and annual gross and net productivity estimates are maximum potential rates and do not reflect the inherent day-to-day climatic variability characteristic of these systems that would make realized rates lower (Wetzel 1983, Wetzel \& Penhale 1983, Wetzel \& Neckles 1986). For comparison with values reported elsewhere, the oxygen data were converted to carbon equivalents by assuming a photosynthetic quotient (PQ) of 1.25 and a respiratory quotient (RQ) of 1.0 (Lindeboom \& deBree 1982, Oviatt et al. 1986).

Plankton $\mathrm{O}_{2}$ production and consumption. Plankton samples were collected using a Van Dorn water sampler from $10 \mathrm{~cm}$ below the water surface and from just above the canopy top in the Zostera marina area. Triplicate light and dark bottle incubations were conducted in standard BOD bottles $(300 \mathrm{ml})$ which were suspended at the depth of collection. For the shallower
Ruppia maritima community samples were collected from and incubated at mid-depth only (ca $25 \mathrm{~cm}$ below the water surface). Oxygen concentrations in the BOD bottles were determined 3 times during each incubation (beginning, middle and end). Areal rates of $\mathrm{O}_{2}$ production and consumption were estimated using the average water depth over the incubation interval.

Sediment $\mathrm{O}_{2}$ production and consumption. Production and consumption of $\mathrm{O}_{2}$ by the sediment community (including microautotrophic and heterotrophic organisms) were estimated using triplicate clear and opaque acrylic chambers covering a sediment surface area of $60 \mathrm{~cm}$ and containing $750 \mathrm{ml}$ of ambient water. Concentrations of $\mathrm{O}_{2}$ were measured 3 times over the incubation interval using a polargraphic electrode (with stirrer) inserted through a port in the top of the chambers. The chambers were placed among the vascular plants but in sediments without seagrass leaves. Sediment $\mathrm{O}_{2}$ production and consumption estimates were corrected for the water (plankton) contribution to $\mathrm{O}_{2}$ changes during incubation. Areal estimates were derived by estimating the bare sediment surface area within the vascular plant communities using percent cover and plant abundance data reported by Orth et al. (1979) and Wetzel (1983).

Seagrass-plus-epiphyte $\mathrm{O}_{2}$ production and consumption. In these seagrass communities the abundance of an attached, epiphytic community was relatively low, representing $<7 \%$ of the combined dry mass of seagrass leaves and epiphytes (Murray 1983). Therefore, rate estimates for epiphytes and the seagrass hosts (seagrass-plus-epiphyte) were combined for the purposes of this study. Rates of $\mathrm{O}_{2}$ production and consumption were calculated as the difference between estimates for the total community and the combined rates of the sediment and plankton. Total community production and consumption were measured as oxygen exchanges under large $(260 \mathrm{l} ; 0.78 \mathrm{~m}$ surface areal plexiglass dome enclosures and are described in detail elsewhere (Wetzel 1983, Wetzel \& Penhale 1983).

\section{RESULTS}

Measurements of $\mathrm{O}_{2}$ production and consumption in Zostera marina and Ruppia maritima communities were conducted during various conditions, with water temperature ranging from 7 to $29^{\circ} \mathrm{C}$. For these studies, light (PAR) conditions at $20 \mathrm{~cm}$ above the sediment within the seagrass canopy were generally at or above photosynthetic saturation intensities for both vascular plants (ca 200 to $400 \mu \mathrm{E} \mathrm{m}^{-2} \mathrm{~s}^{-1}$; Wetzel \& Penhale 1983) and microalgae (ca 30 to $100 \mu \mathrm{E} \mathrm{m}^{-2} \mathrm{~s}^{-1}$; Cadee \& Hegeman 1974, Admiraal 1977). However, for $Z$. marina during April, early October and January studies 
and for $R$. maritima during the October study PAR levels were below saturation. Experimental conditions for all studies are summarized in Table 1.

Net apparent productivity (NAP; $\mathrm{O}_{2}$ evolution during daylight hours) and respiration (as oxygen consumption) estimates for Zostera marina communities were dominated by the seagrass-plus-epiphyte component during winter, spring and late fall, while during midsummer plankton contributions were of greater importance (Fig. 2). This shift in relative productivity corresponds with a mid to late summer die-back of $Z$. marina, which is characteristic for these seagrass populations in lower Chesapeak Bay (Wetzel 1983, Wetzel \& Penhale
1983). Respiration of the seagrass-plus-epiphyte component increased as NAP decreased following a May peak in productivity, indicating a lag between production and respiration. In contrast, the plankton and sediment components exhibited close temporal correspondence of NAP and respiration throughout the year.

Net apparent productivity and respiration (Fig. 3) for Ruppia maritima exhibited summer peaks in activity, which is consistent with maximum biomass for $R$. maritima during mid to late summer (Orth et al. 1979, Wetzel 1983). Compared to the Zostera marina community, the $R$. maritima seagrass-plus-epiphyte complex clearly dominated throughout the study period.

Table 1. Experimental conditions during $\mathrm{O}_{2}$ production and respiration studies at 2 seagrass sites. Data given are arithmetic means over incubation period

\begin{tabular}{|c|c|c|c|c|c|c|}
\hline \multirow[t]{2}{*}{ Month \& Date } & \multirow{2}{*}{$\begin{array}{l}\text { Seagrass } \\
\text { system }\end{array}$} & \multirow{2}{*}{$\begin{array}{c}\text { Temperature } \\
\left({ }^{\circ} \mathrm{C}\right)\end{array}$} & \multicolumn{2}{|c|}{$\operatorname{PAR}\left(\mu \mathrm{E} \mathrm{m}^{-2} \mathrm{~s}^{-1}\right)^{\cdot}$} & \multicolumn{2}{|c|}{ Seagrass abundance " } \\
\hline & & & Surface & Bottom & $\begin{array}{c}\text { Biomass } \\
\left(\mathrm{g} d w t \mathrm{~m}^{-2}\right)\end{array}$ & $\begin{array}{l}\text { Cover } \\
(\%)\end{array}$ \\
\hline \multicolumn{7}{|l|}{ March } \\
\hline 10 Mar 81 & Zostera & 8 & nd & 266 & nd & nd \\
\hline \multicolumn{7}{|l|}{ April } \\
\hline 9 Apr 81 & Zostera & 14 & 396 & 104 & nd & nd \\
\hline \multicolumn{7}{|l|}{ May } \\
\hline 8 May 81 & Zostera & 16 & 1860 & 275 & 96 & 93 \\
\hline 22 May 81 & Zostera & 18 & 1664 & 395 & 81 & 85 \\
\hline \multicolumn{7}{|l|}{ June } \\
\hline 15 Jun 81 & Zostera & 26 & 1593 & 323 & 116 & 100 \\
\hline 14 Jun 81 & Ruppia & 24 & nd & 627 & 20 & nd \\
\hline 30 Jun 81 & Ruppia & 25 & nd & nd & 34 & nd \\
\hline \multicolumn{7}{|l|}{ July } \\
\hline 13 Jul 81 & Zostera & 33 & 1183 & 266 & 62 & 70 \\
\hline 15 Jul 81 & Ruppia & 24 & nd & 720 & 80 & nd \\
\hline \multicolumn{7}{|l|}{ August } \\
\hline 4. Aug 81 & Zostera & 27 & 1645 & 294 & 61 & 69 \\
\hline 25 Aug 81 & Zostera & 26 & 1650 & 285 & 19 & 28 \\
\hline 4 Aug 81 & Ruppia & 27 & nd & 355 & 82 & nd \\
\hline 26 Aug 81 & Ruppia & 25 & nd & 469 & 87 & nd \\
\hline \multicolumn{7}{|l|}{ September } \\
\hline 13 sep of & Kuppid & 27 & ind & $3+2$ & 01 & no \\
\hline \multicolumn{7}{|l|}{ October } \\
\hline $\begin{array}{l}13 \text { Oct } 81 \\
22 \text { Oct } 81\end{array}$ & $\begin{array}{l}\text { Zostera } \\
\text { Zostera }\end{array}$ & $\begin{array}{l}20 \\
16\end{array}$ & $\begin{array}{l}1204 \\
1191\end{array}$ & $\begin{array}{l}125 \\
222\end{array}$ & $\begin{array}{l}24 \\
\text { nd }\end{array}$ & $\begin{array}{l}33 \\
\text { nd }\end{array}$ \\
\hline $\begin{array}{l}22 \text { Oct } 81 \\
13 \text { Oct } 81\end{array}$ & $\begin{array}{l}\text { Zostera } \\
\text { Ruppia }\end{array}$ & $\begin{array}{l}16 \\
20\end{array}$ & 1191 & $\begin{array}{l}222 \\
125\end{array}$ & 70 & nd \\
\hline \multirow{2}{*}{\multicolumn{7}{|c|}{ January }} \\
\hline & & & & & & \\
\hline \multicolumn{7}{|c|}{$\begin{array}{l}\text { PAR is photosynthetically active radiation }(400 \text { to } 700 \mathrm{~nm}) \text {; surface refers to measurements in air; bottom indicates in water } \\
20 \mathrm{~cm} \text { from sediment surface } \\
\text { - Biomass data from Wetzel (1983); percent cover estimated using these biomass data and a biomass-\% cover regression ( } \mathrm{r}= \\
\text { 0.95) developed from data of Orth et al. (1979) } \\
\text { nd: not determined }\end{array}$} \\
\hline
\end{tabular}




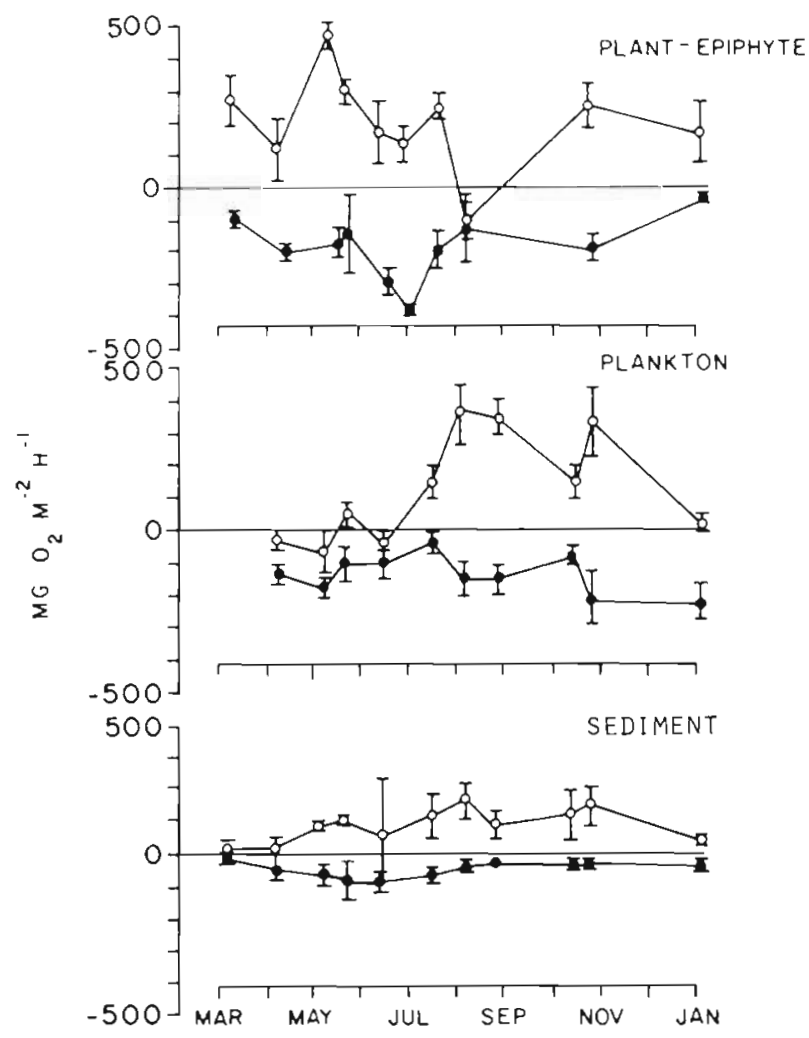

Fig. 2. Zostera marina dominated community. Mean ( $\pm \mathrm{SD}$ ) areal estimates of net apparent productivity (o) and respiration (•) for the 3 autotrophic components

The July peak in seagrass-plus-epiphyte NAP coincided with the decline in NAP of the same component in the Z. marina community. Respiration for R. maritima (plus epiphytes) tracked NAP during the initial growth period but increased during plant die-back in the fall. Plankton and sediment metabolic rates were considerably lower and only comprised a maximum of $30 \%$ of the total community NAP or respiration. Both components exhibited higher productivity rates during early summer (June to August), but declined in late summer and fall. Plankton respiration rates followed NAP rates. However, sediment respiration exhibited an increase in rate (August) corresponding to the decline in plant NAP.

Seasonal and annual estimates of gross production (defined as the algebraic sum of NAP and respiration) for the Zostera marina community and its epiphytes accounted for between 37 and $80 \%$ of total gross production depending on season, with annual rates of ca $867 \mathrm{gC} \mathrm{m}^{-2} \mathrm{yr}^{-1}$ (Table 2). Plankton and sediment gross production ranged from 10 to $48 \%$ and 10 to $25 \%$ of the total with annual rates of ca 488 and $225 \mathrm{gC}$ $\mathrm{m}^{-2} \mathrm{yr}^{-1}$, respectively. Respiration of the seagrass and epiphytes dominated the total for all seasons except winter, accounting for $42 \%$ of total annual $\mathrm{O}_{2}$ consumption. Respiration rates for plankton and sediment

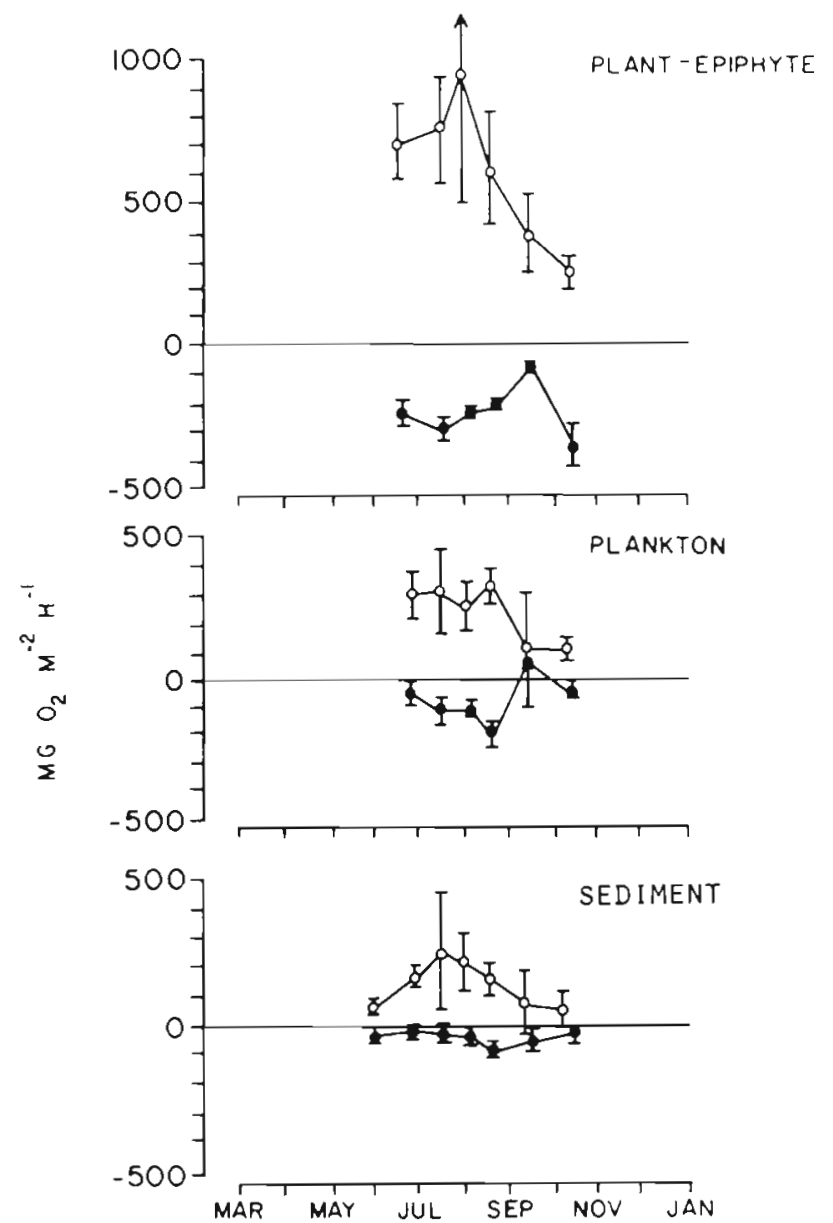

Fig. 3. Ruppia maritima dominated community. Mean ( \pm SD) areal estimates of net apparent productivity $(O)$ and respiration $(\bullet)$ for the 3 autotrophic components

communities were relatively important in winter and summer seasons, respectively.

In the Ruppia maritima community (Table 3) gross production by seagrass-plus-epiphytes constituted a greater proportion of the total, ranging from 44 to $76 \%$, with an annual contribution of $707 \mathrm{gC} \mathrm{m}^{-2} \mathrm{yr}^{-1}$. This estimate of annual production assumes that winter productivity of $R$. maritima is negligible, an assumption consistent with observations of denudation associated with ice sheeting and natural mortality (Murray 1983). The combined annual contributions of all microalgae components was considerably less important in this community compared to the Zostera marina system (36 vs $45 \%$ of the total). The partitioning of total respiration in the $R$. maritima community was similar to that for gross production.

The ratio of daily production to respiration $(P: R)$ indicates the balance between autochthonous production and consumption of organic matter for each component in the 2 communities (Tables 2 \& 3). Overall, $\mathrm{P}: \mathrm{R}$ ratios for total community metabolism were gener- 
Table 2. Seasonal and annual estimates of gross production $(P)$ and respiration $(R)\left(\mathrm{gC} \mathrm{m}^{-2}\right)$ by the principal components and total community in the Zostera marina area $(\mathrm{n}=11)$

\begin{tabular}{|c|c|c|c|c|c|c|c|c|c|c|c|}
\hline \multirow[t]{2}{*}{ Component } & \multicolumn{2}{|c|}{ Winter } & \multicolumn{2}{|c|}{ Spring } & \multicolumn{2}{|c|}{ Summer } & \multicolumn{2}{|c|}{ Fall } & \multicolumn{3}{|c|}{ Annual total" } \\
\hline & $P$ & $\mathrm{R}$ & $\mathrm{P}$ & $\mathrm{R}$ & $\mathrm{P}$ & $\mathrm{R}$ & $\mathrm{P}$ & $\mathrm{R}$ & $\mathrm{P}$ & $\mathrm{R}$ & Net \\
\hline Seagrass-plus-epiphytes & 330 & 53 & 289 & 105 & 161 & 140 & 87 & 117 & 867 & 415 & 452 \\
\hline$\%$ of total & 55 & 18 & 80 & 51 & 41 & 47 & 37 & 60 & 55 & 42 & 76 \\
\hline Component P:R & \multicolumn{2}{|c|}{6.2} & \multicolumn{2}{|c|}{2.8} & \multicolumn{2}{|c|}{1.2} & \multicolumn{2}{|c|}{0.74} & \multicolumn{2}{|c|}{2.1} & \\
\hline Plankton & 205 & 213 & 36 & 72 & 134 & 87 & 113 & 62 & 488 & 434 & 54 \\
\hline$\%$ of total & 34 & 73 & 10 & 35 & 34 & 30 & 48 & 32 & 31 & 44 & 9 \\
\hline Component P:R & \multicolumn{2}{|c|}{0.96} & \multicolumn{2}{|c|}{0.50} & \multicolumn{2}{|c|}{1.5} & \multicolumn{2}{|c|}{1.8} & \multicolumn{2}{|c|}{1.1} & \\
\hline Sediment & 63 & 25 & 32 & 30 & 95 & 68 & 35 & 15 & 225 & 138 & 87 \\
\hline$\%$ of total & 11 & 9 & 10 & 14 & 25 & 23 & 15 & 8 & 14 & 14 & 15 \\
\hline Component P:R & \multicolumn{2}{|c|}{2.5} & \multicolumn{2}{|c|}{1.1} & \multicolumn{2}{|c|}{1.4} & \multicolumn{2}{|c|}{2.3} & \multicolumn{2}{|c|}{1.6} & \\
\hline Total & 598 & 291 & 357 & 207 & 390 & 295 & 235 & 194 & 1580 & 987 & 593 \\
\hline$P: R$ & \multicolumn{2}{|c|}{2.0} & \multicolumn{2}{|c|}{1.7} & \multicolumn{2}{|c|}{1.3} & \multicolumn{2}{|c|}{1.2} & \multicolumn{2}{|c|}{1.6} & \\
\hline
\end{tabular}

ally $>1.0$ for both communities, the notable exceptions being the seasonal die-back periods for both vascular plant species. In terms of organic matter input to the communities (i.e. excess production versus respiration), the relatively high production rates combined with high $P: R$ ratios for seagrass-plus-epiphyte components in both systems indicated their dominant importance. Although P:R ratios were high for the sediment communities (especially in the shallower Ruppia maritima system), their overall inputs to the respective community budgets for organic matter are relatively low. A lag between production and consumption for the seagrassplus-epiphyte component is evident in that peak pro- duction occurs in the spring for both communities, while peak consumption occurs in summer and fall for Zostera marina and $R$. maritima communities, respectively.

Pair-wise linear regressions between metabolic rates and selected environmental parameters (temperature and light), as well as vascular plant biomass revealed that respiration was significantly correlated with temperature for all components in the Zostera marina community, as might be expected. In this system, net productivity was positively correlated with temperature for the sediment $(\mathrm{r}=0.65 ; \mathrm{n}=11)$ suggesting microalgal response to temperature increases. No significant cor-

Table 3. Seasonal and annual estimates of gross production $(P)$ and respiration $(R)\left(\mathrm{gC} \mathrm{m}^{-2}\right)$ by the principal components and total community in the Ruppia maritima area ( $n=16$ )

\begin{tabular}{|c|c|c|c|c|c|c|c|c|c|}
\hline \multirow[t]{2}{*}{ Component } & \multicolumn{2}{|c|}{ Spring } & \multicolumn{2}{|c|}{ Summer } & \multicolumn{2}{|c|}{ Fall } & \multicolumn{3}{|c|}{ Annual total } \\
\hline & $\mathrm{P}$ & $\mathrm{R}$ & $\mathrm{P}$ & $\mathrm{R}$ & $P$ & $\mathrm{R}$ & $\mathrm{P}$ & $\mathrm{R}$ & Net \\
\hline Seagrass-plus-epiphyte & 306 & 192 & 259 & 128 & 142 & 172 & 707 & 492 & 215 \\
\hline$\therefore$ of total & 76 & 76 & 69 & 80 & 44 & 46 & 64 & 62 & 69 \\
\hline Component P:R & \multicolumn{2}{|c|}{1.6} & \multicolumn{2}{|c|}{2.0} & \multicolumn{2}{|c|}{0.8} & \multicolumn{2}{|c|}{1.4} & \\
\hline Plankton & 66 & 54 & 71 & 27 & 150 & 190 & 287 & 291 & 16 \\
\hline$\%$ of total & 16 & 22 & 19 & 17 & 46 & 50 & 26 & 34 & 5 \\
\hline Component $\mathrm{P}: \mathrm{R}$ & \multicolumn{2}{|c|}{1.2} & \multicolumn{2}{|c|}{2.6} & \multicolumn{2}{|c|}{0.8} & \multicolumn{2}{|c|}{1.1} & \\
\hline Sediment & 30 & 5 & 45 & 6 & 31 & 15 & 106 & 26 & 80 \\
\hline of total & 8 & 2 & 12 & 3 & 10 & 4 & 10 & 4 & 26 \\
\hline Component $\mathrm{P}: \mathrm{R}$ & \multicolumn{2}{|c|}{6.0} & \multicolumn{2}{|c|}{7.5} & \multicolumn{2}{|c|}{2.1} & \multicolumn{2}{|c|}{4.1} & \\
\hline Total & 402 & 251 & 375 & 161 & 323 & 377 & 1100 & 789 & 311 \\
\hline$P: R$ & \multicolumn{2}{|c|}{$1.6^{401}$} & \multicolumn{2}{|c|}{2.3} & \multicolumn{2}{|c|}{0.8} & \multicolumn{2}{|c|}{1.4} & \\
\hline
\end{tabular}


relation could be found between PAR and NAP for any component in the $Z$. marina community, indicating that light was not limiting. This result is as expected due to the experimental design; i.e. incubations were conducted during optimal light conditions. Biomass of $Z$. marina was positively correlated with seagrassepiphyte respiration, but negatively correlated with benthic respiration $(\mathrm{r}=-0.76 ; \mathrm{n}=11)$. These correlations may suggest plant senescence after peaks plantgrowth periods, and shading of sediment microalgae by the seagrass. NAP of both the Ruppia maritima seagrass-plus-epiphyte and the sediment community were positively correlated with temperature (see above) ( $\mathrm{r}=0.62,0.61, \mathrm{P}<0.10 ; \mathrm{n}=6$ ); however, respiration was not significantly correlated with temperature for any of the components perhaps due to experimental design (i.e. no winter measurements). Productivities of both $R$. maritima and associated sediment community were weakly correlated with light $(\mathrm{r}=0.61,0.62, \mathrm{P}<0.10 ; \mathrm{n}=6)$, again as expected due to experimental design. Plankton productivity in the shallow $R$. maritima area, however, was negatively correlated with light $(r=-0.70, P<0.10 ; \quad n=6)$, perhaps due to photoinhibition (Fisher et al. 1982).

\section{DISCUSSION}

Annual rates of net production of seagrasses (plus epiphytes) in this study were ca 300 and $500 \mathrm{gC} \mathrm{m}^{-2}$ for Ruppia maritima and Zostera marina, respectively, which corresponds well with measurements reported for these species using a variety of techniques (Dillon 1971. McRoy 1974, Verhoeven 1979, Neinhuis 1980, Thorne-Miller \& Harlin 1984). In the Z. marina community annual mean epiphyte biomass was $<10 \%$ of the total combined seagrass-plus-epiphyte (above ground) dry weight, and epiphyte production (NAP) was $<7 \%$ of the combined rate for the community (Murray 1983). These epiphytic biomass and production rates are low compared to other temperate seagrass systems which typically range from 25 to $60 \%$ (Penhale 1977, Borum \& Wium-Andersen 1980, Morgan \& Kitting 1984). Seagrasses (and their epiphytes) here contributed 55 and $64 \%$ of the total annual carbon produced in the $Z$. marina and the $R$. maritima communities, respectively. The remaining autochthonous production was provided by the associated sediment and planktonic communities.

Net production estimates for individual microalgal (plankton \& sediment) components in these seagrass communities were similar to those of other studies. Annual production for the sediment community in the Zostera marina and the Ruppia maritima communities were 225 and $106 \mathrm{gC} \mathrm{m}^{-2}$, respectively. These values are in the range of previous reports for production in a variety of sediment types (Pomeroy 1959, Grontved 1960, Pamatmat 1968, Marshall et al. 1971, Riznyk \& Phinney 1972, Joint 1978, Zelder 1980, Rizzo \& Wetzel 1985, Rizzo 1986). The contributions of the sediment to total annual production in these seagrass systems were 3 and $14 \%$ which brackets the $8 \%$ reported by Thayer et al. (1975) for a Z. marina community in North Carolina. Net annual plankton production estimates for the $Z$. marina and $R$. maritima areas in this study were 488 and $287 \mathrm{gC} \mathrm{m}^{-2}$, respectively. Increased in situ light conditions and close coupling of sediment-water column remineralization may account for these relatively high rates of plankton production.

Although overall production values for the 2 communities are similar, the seasonal patterns and relative contributions of individual components were quite different. In the Zostera marina area a summer decline in seagrass production was observed. However, net community production remained high because increased microalgal production during this period compensated for decreased seagrass production. On the other hand, seagrass-plus-epiphyte production in the Ruppia maritima community was positively correlated with temperature, and peak production occurred in mid-summer followed by a decline in fall. Here, microalgae followed a seasonal pattem similar to that of the seagrass. Thus, the decline in seagrass production was not accompanied by an increase in production of the plankton and sediment communities.

Respiration values provide a further indication of differences between the 2 communities in relation to heterotrophic utilization of primary production. The combined respiration of plankton and sediment accounted for $58 \%$ of total respiration in the Zostera marina area, compared to $38 \%$ in the Ruppia maritima system, indicating a greater importance of water-column and sediment food chains in the former. Relatively high respiration rates for the seagrass-plus-epiphyte component of both communities during summer may reflect increases in both respiration (Bieble \& McRoy 1971) and excretion of dissolved organic carbon (and associated bacterial respiration; Kirchman et al. 1984) resulting from elevated temperatures. The increased respiration and decreased $P: R$ ratios of the seagrass (plus epiphytes) in both communities and especially $R$. maritima probably indicate plant senescence and heterotrophic decomposition of seagrass stands (Godshalk \& Wetzel 1978). In both areas, the seagrass-plusepiphyte component exhibited a lag between production and respiration, suggesting perhaps that heterotrophic utilization of seagrass production is indirect (i.e. utilized via detrital pathways). Further support for this concept is evident in the seasonal sequence of $P: R$ ratios for the seagrass-plus-epiphyte complex. In both 
the $Z$. marina and $R$. maritima areas, $P: R$ declined following peaks in NAP (i.e. late summer and fall, respectively). This trend is consistent with the concept that seagrass production is utilized predominantly through decomposition processes (Hargrave 1969, Lindeboom \& deBree 1982, Wetzel 1983). In contrast, the microalgal components exhibited a strong temporal correspondence between NAP and respiration, suggesting more direct pathways for utilization of production. However, benthic respiration in the $R$. maritima area was more closely coupled with the onset of seagrass die-back, with peak rates in August.

We have demonstrated here that autotrophic communities associated with 2 temperate seagrasses are characterized by high rates of oxygen (and presumably organic matter) production, and that the seagrasses plus epiphytes themselves contribute only 55 to $64 \%$ of the total gross production. Most previous studies have ignored one or more of the microalgal components of these communities, thereby, at least potentially, underestimating total primary production. The 2 seagrass communities studied here exhibited distinctly different temporal patterns of production, one of which (Zostera marina) was asynchronous with that of the sediment plus planktonic algae and the other of which (Ruppia maritima) corresponded closely to the temporal sequence of microalgal production. Indirect evidence suggests that microalgal production is utilized more directly than that of seagrasses, and annual carbon budgets estimated for those 2 systems indicate that there is excess autochthonous (the value would be even greater if equivalent $P Q$ and $R Q$ values were used) production (above consumption) which is either buried in place or exported to contiguous estuarine habitats.

Acknowledgements. We thank the many colleagues who helped make this study possible, and especially $R$. vanTine, $R$. Hoffman and A. Evans for their support in field studies. In addition, we thank J. Borum, W. M. Kemp, R. J. Orth, K. L. Webb and 3 anonymous reviewers for critical reviews of earlier drafts of the manuscript. This research was supported by Grants R805974 and X003245 from the U.S. Environmental Protection Agency, Chesapeake Bay Program, Annapolis, Maryland.

\section{LITERATURE CITED}

Admiraal, W. (1977). Influence of light and temperature on the growth rate of estuarine benthic diatoms in culture. Mar. Biol. 39: 1-9

Biebel, R., McRoy, C. P. (1971). Plasmatic resistance and rate of respiration and photosynthesis of Zostera marina at different salinities and temperatures. Mar. Biol. 8(1): 48-56

Borum, J., Wium-Andersen, S. (1980). Biomass and production of epiphytes on eelgrass (Zostera marina L.) in the Oresund, Denmark. Ophelia 1 (Suppl.): 57-64.

Cadee, G. C., Hegeman, J. (1974). Primary production of the benthic microflora living on tidal flats in the Dutch Wadden Sea. Neth. J. Sea Res. 11: $24-41$
Cattaneo, A., Kalff, J. (1980). The relative contribution of aquatic macrophytes and their epiphytes to the production of macrophyte beds. Limnol. Oceanogr 25: 280-289

Dillon, C. R. (1971). A comparative study of the primary productivity of estuarine phytoplankton and macrobenthic plants. Ph. D. thesis, Univ. North Carolina, Chapel Hill

Fisher, T. R., Carlson, P. R., Barber, R. T (1982). Carbon and nitrogen primary productivity in three North Carolina estuaries. Estuar. coast. Shelf Sci. 15: 621-644

Godshalk, G. L., Wetzel, R. G. (1978). Decomposition of aquatic angiosperms. III. Zostera marina $\mathrm{L}$. and a conceptual model of decomposition. Aquat. Bot. 5: 329-354

Grontved, J. (1960). On the productivity on microbenthos and phytoplankton in some Danish fjords. Meddr Danm. Fisk.og Havunders. 3: 55-92

Hargrave, B. T. (1969). Epiphytic algae production and community respiration in the sediments of Marion Lake. J. Fish. Res. Bd Can. 26: 2003-2026

Heck, K. L., Orth, R. J. (1980). Structural components of eelgrass (Zostera marina) meadows in the lower Chesapeake Bay - Decapod crustaceans. Estuaries 3: 289-295

Joint, I. R. (1978). Microbial production of an estuarine mudflat. Estuar. cost mar Sci. 7: 185-195

Kirchman, D. L., Mazzella, L., Alberte, R. S., Mitchell, R. (1984). Epiphytic bacterial production on Zostera marina. Mar. Ecol. Prog. Ser. 15: 117-123

Lindeboom, H. J., deBree, B. H. (1982). Daily production and consumption in an eelgrass (Zostera marina) community in saline Lake Grevelingen: discrepancies between the $\mathrm{O}_{2}$ and ${ }^{14} \mathrm{C}$ method. Report to Delta Institute of Hydrobiological Research, Yerseke, The Netherlands

Marshall, N., ONiatt, C. A., Skauen, D. M. (1971). Productivity of the benthic microflora of shoal estuarine environments in southern New England. Int. Revue ges. Hydrobiol. 56: $947-956$

McRoy, C. P. (1974). Seagrass productivity, carbon uptake experiments in eelgrass, Zostera marina. Aquaculture 4: 131-137

Morgan, M. D. (1980). Grazing and predation of the grass shrimp Palaemonetes pugio. Limnol. Oceanogr 25(5): 896-902

Morgan, M. D., Kitting, C. L. (1984). Productivity and utilization of the seagrass Halodule wrightii and its attached epiphytes. Limnol. Oceanogr 29: 1066-1076

Murray, L. (1983). Metabolic and structural studies of several temperate seagrass communities, with emphasis on microalgal components. Ph. D. thesis, College of William and Mary, Gloucester Point, Virginia

Neinhuis, P. H. (1980). The eelgrass (Zostera marina L.) subsystem in brackish Lake Grevelingen: production and decomposition of organic matter. Ophelia 1 (Suppl.): $113-116$

Nixon, S. W., Oviatt, C. A. (1972). Preliminary measurements of midsummer metabolism in beds of eelgrass, Zostera marina. Ecology 53: 150-153

Orth, R. J. (1973). Benthic infauna of eelgrass, Zostera marina, beds. Chesapeake Sci. 14: 258-259

Orth, R. J., Moore, K. A., Gordon, H. H. (1979). Distribution and abundance of submerged aquatic vegetation in the lower Chesapeake Bay. U.S. Environmental Protection Agency, Report no. 600/8-79-029/SAV1, Chesapeake Bay Program, Annapolis, Maryland

Oviatt, C. A., Rudnick, D. T., Keller, A. A., Sampow, P. A., Almquist, $G$. $T$ (1986). A comparison of system $\left(\mathrm{O}_{2}\right.$ and $\mathrm{CO}_{2}$ ) and ${ }^{14} \mathrm{C}$ measurements of metabolism in estuarine mesocosms. Mar. Ecol. Prog. Ser. 28: 57-67

Pamatmat, M. M. (1968). Ecology and metabolism of a benthic 
community on an intertidal sandflat. Int. Revue ges. Hydrobiol. 53: 211-298

Penhale, P. A. (1977). Macrophyte-epiphyte biomas and productivity in an eelgrass (Zostera marina L.) community. J. exp. mar. Biol. Ecol. 26: 211-224

Pomeroy, L. R. (1959). Algal productivity in salt marshes of Georgia. Limnol. Oceanogr. 4: 386-397

Riznyk, R. Z., Phinney, H. K. (1972). Nanometric assessment of interstitial microalgae production in two estuarine sediments. Oecologia (Berl.) 10: 193--203

Rizzo, W. M. (1986). The community metabolism and nutrient dynamics of a shoal sediment in a temperature estuary, with emphasis on temporal scales of variability. $\mathrm{Ph} . \mathrm{D}$. dissertation, College of William and Mary, Williamsburg, Virginia

Rizzo, W. M., Wetzel, R. L. (1985). Intertidal and shoal benthic community metabolism in a temperate estuary: studies of spatial and temporal scales of variability. Estuaries 8: 342-351

Sondergaard, M., Sand-Jensen, K. (1978). Total autotrophic production in oligotrophic Lake Kalgaard, Denmark. Verh. int. Verein. Limnol. 29: 667-673

Stoner, A. W. (1980). Feeding ecology of Lagodon rhomboides (Pisces: Sparidea): variation and function responses. Fish. Bull. U.S. $78(2)$ : $337-352$

Thayer, G. W., Adams, S. M., La Criox, M. W. (1975). Structural and functional aspects of a recently established Zostera marina community. In: Cronin, L. E. (ed.) Estuarine research, Vol. 1. Academic Press, New York, p. 518-546

Thorne-Miller, B., Harlin, M. M. (1984). The production of Zostera marina $\mathrm{L}$. and other submerged macrophytes in a coastal lagoon in Rhode Island, USA. Botanica mar. 27: $539-546$

Verhoeven, J. T. A. (1979). The ecology of Ruppia-dominated communities in Western Europe. I. Distribution of Ruppia representatives in relation to their autecology. Aquat. Bot. 6: $197-268$

Wetzel, R. G. (1964). A comparative study of the primary productivity of higher aquatic plants, periphyton and phytoplankton in a large, shallow lake. Int. Revue ges. Hydrobiol. 49: 1-61

Wetzel, R. L. (1983). Structural and functional aspects of the ecology of submerged aquatic macrophyte communities in the lower Chesapeake Bay. Final Report No. 267, U.S. Environmental Protection Agency, Chesapeak Bay Program, Annapolis, Maryland

Wetzel, R. L., Penhale, P. A. (1983). Production ecology of seagrass communities in the lower Chesapeake Bay. Mar. Tech. Soc. J. 17(2): 22-31

Wetzel, R. L., Neckles, H. A. (1986). A model of Zostera marina L. photosynthesis and growth: simulated effects of selected physical-chemical variables and biological interactions. Aquat. Bot. 26: 307-323

Zelder, J. B. (1980). Algal mat productivity: comparisons in a salt marsh. Estuaries 3: 122-131

Zieman, J. C., Wetzel, R. G. (1980). Productivity in seagrasses: methods and rates. In: Phillips, R. C., McRoy, C. P. (ed.) Handbook of seagrass biology: an ecosystem perspective. Garland STPM Press, New York, p. 87-118

Zimmerman, R., Gibson, R., Harrington, J. (1979). Herbivory and detritivory among gammaridean amphipods from a Florida seagrass community. Mar. Biol. 54: 41-47

This article was presented by Professor S. W. Nixon; it was accepted for printing on April 13, 1987 